\title{
Investigation and modeling of the effect of pre-deformation of austenite on the kinetics of ferritic transformation
}

\author{
A. A. Vasilyev ${ }^{\dagger, 1}$, D. F. Sokolov², S. F. Sokolov ${ }^{2}$ \\ †vasilyev_aa@mail.ru
}

${ }^{1}$ Peter the Great St. Petersburg Polytechnic University, St. Petersburg, 195251, Russia

${ }^{2}$ PJSC Severstal, Cherepovets, 162608, Russia

\begin{abstract}
The kinetics of transformation of undeformed and deformed austenite during continuous cooling has been investigated on several industrial steels. Dimensions of both prior austenite grains and ferrite grains in ferrite-pearlite structures obtained for various states of the parent austenite and cooling rates have been determined. At low cooling rates, no notable effect of austenite deformation on the temperature of the onset of ferritic transformation has been found. This effect gains in significance at higher cooling rates that is seemingly due to a weaker recovery of the deformed austenite. Similarly, the deformation of austenite influences the temperature of the transformation finish, although in this case the effect of the cooling rate on the increase of this temperature is lesser. As expected, the pre-deformation of the austenite shifts the transformation range to higher temperatures. Based on the obtained experimental data, a physically motivated model is formulated for the ferritic transformation with allowance for the effects of deformation and concurrent recovery of austenite. To predict properly the nucleation rate, the variation of nucleation barriers at the austenite grain boundaries is considered, which is due to the hydrostatic component of the deformation-induced internal stresses. The present model is first to allow for this effect exponentially increasing the nucleation rate. The simulated kinetics of the ferritic-pearlitic transformation in the investigated steels satisfactorily comply with the experiments. Experimental verification of the ferrite grain sizes predicted for both undeformed and deformed austenite is satisfactory as well. The relative errors of these predictions averaged over all considered steels, are 10.8 and $13.2 \%$, respectively.
\end{abstract}

Keywords: austenite, deformation, ferrite, transformation, modeling.

УДК: 538.91:669.018

\section{Исследование и моделирование влияния предварительной деформации аустенита на кинетику ферритного превращения}

\author{
Васильев А. А. ${ }^{\dagger, 1}$, Соколов Д. Ф. ${ }^{2}$, Соколов С. $Ф{ }^{2}$ \\ ${ }^{1}$ Санкт-Петербургский политехнический университет Петра Великого, Санкт-Петербург, 195251, Россия \\ ${ }^{2}$ ПАО Северсталь, Череповец, 162608, Россия
}

На ряде промышленных сталей исследована кинетика превращения недеформированного и деформированного аустенита при непрерывном охлаждении. Определены размеры как исходных зерен аустенита, так и зерен феррита в ферритно-перлитных структурах, полученных для различных состояний аустенита и скоростей охлаждения. При низких скоростях охлаждения не обнаружено заметного влияния деформации аустенита на повышение температуры начала ферритного превращения. Этот эффект усиливается с ростом скорости охлаждения, что, видимо, связано с уменьшением степени возврата деформированного аустенита. Аналогично деформация аустенита влияет на температуру конца превращения, хотя в этом случае эффект роста скорости охлаждения на повышение данной температуры выражен слабее. Как ожидалось, предварительная деформация аустенита смещает диапазон превращения в сторону более высоких температур. На основе полученных экспериментальных данных сформулирована физически мотивированная модель ферритного превращения с учетом эффектов деформации и возврата аустенита. Для адекватного учета влияния деформации на скорость зарождения зерен феррита 
рассмотрено изменение энергетических барьеров зарождения феррита на границах зерен аустенита, обусловленное гидростатической составляющей индуцированных деформацией внутренних напряжений на этих границах. Настоящая модель впервые учитывает данный эффект, приводящий к экспоненциальному увеличению скорости зарождения. Результаты моделирования кинетики ферритно-перлитного превращения в исследуемых сталях хорошо согласуются с экспериментом. Точность предсказания размеров зерна феррита как для недеформированного, так и для деформированного аустенита, также является удовлетворительной. Относительные погрешности этих предсказаний, усредненные по всем рассматриваемым сталям, составляют 10.8 и 13.2\%, соответственно.

Ключевые слова: аустенит, деформация, феррит, превращение, моделирование.

\section{Introduction}

Finish stages of industrial hot rolling of microalloyed HSLA steels are often implemented at appropriately low temperatures, so that the deformation induced precipitation of carbo-nitrides hinders recrystallization of austenite [1]. Thus, retained strain accumulates that affects the fractions and morphologies of specific structural constituents produced by the phase transformation in subsequent accelerated cooling as well as the final mechanical properties of steel. Related quantitative models should allow for the austenite deformation effect on the formation of all transformation products, including ferrite. Although the latter is not the main structure component of high strength steels, its appearance at the initial transformation stage significantly influences the subsequent formation of bainite that essentially determines the material properties [2].

There are a number of works [3-8] devoted to the experimental study and modeling of the pre-deformation effect on the transformation of austenite to ferrite in continuous cooling. It is accepted that this effect accelerates the transformation as displayed by an increase in its start and finish temperatures. It is also accepted as well that the deformation leads to a certain reduction in the grain size of ferrite. The relevant data evidence that the main factor accelerating the transformation is a less required overcooling. It is also worth noting that the latter is hardly due to a higher dislocation density in deformed austenite, since the respective increase in its specific energy is insufficient.

According to $[9,10]$, the rate of any nucleation process exponentially increases with a variation of the corresponding energy barriers around their average value. The authors believe that such variations may appear in deformed austenite as far as the interaction of its constitutive grains results in strong stress singularities at grain ribs [11] and apexes. Owing to the volumetric effect of the $\gamma \rightarrow \alpha$ transformation in steel, the hydrostatic components of the internal stresses will affect the nucleation whereas their alternate signs naturally comply with the general concept of "static disorder" $[9,10]$. Specifically, in comparison with undeformed austenite, the transformation starts at lower overcooling due to positive (tensile) hydrostatic stresses in some local domains, although the process is delayed in other local domains where the hydrostatic component is negative. The present paper is the first to model the considered effect and to verify it.

Based on the obtained results, a physically motivated model is formulated for the ferritic transformation with allowance for the effects of deformation and the concurrent recovery of austenite.

\section{Materials and experimental methods}

The chemical compositions of the investigated steels produced at PJSC Severstal are shown in Table 1. To analyze the effect of pre-deformation on the transformation of austenite under continuous cooling, a thermomechanical simulator Gleeble 3800 has been employed. Austenitizing temperatures and holding time are selected to avoid excessive grain growth. After rapid cooling to the deformation temperature, the test samples are hold for $5 \mathrm{~s}$ or compressed at a strain rate of $1 \mathrm{~s}^{-1}$ to the true strain $\varepsilon=0.4$ and hold for $5 \mathrm{~s}$. Then various cooling rates $\left(1,3,10,30\right.$ и $\left.100^{\circ} \mathrm{C} / \mathrm{s}\right)$ to room temperature are applied. To prevent the dynamic transformation of austenite to ferrite [12], the deformation temperatures are above $A_{3}^{P E}$ corresponding to the para-equilibrium of ferrite and austenite according to Thermo-Calc calculations [13]. No transformation during deformation of austenite has been verified by dilatometry data. Besides, with slow cooling $\left(1^{\circ} \mathrm{C} / \mathrm{s}\right)$ in the ferrite temperature range, thin ferrite layers along prior austenite grain boundaries (PAGB) have been formed and then have been revealed by etching in a 3\% water solution of picric acid at $80^{\circ} \mathrm{C}$. Quenching temperatures were selected to get a ferrite volume fraction of about $10 \%$. The ferrite-pearlite microstructures have been revealed at room temperature with Nital etchant. Planar sections were prepared by standard metallographic procedures and

Table 1. Chemical compositions (wt.\%) of the investigated steels.

\begin{tabular}{|c|c|c|c|c|c|c|c|c|c|}
\hline Steel & $\mathrm{C}$ & $\mathrm{Mn}$ & $\mathrm{Si}$ & $\mathrm{Cr}$ & $\mathrm{Ni}$ & $\mathrm{Mo}$ & $\mathrm{Nb}$ & $\mathrm{V}$ & $\mathrm{Ti}$ \\
\hline S1 & 0.06 & 0.17 & 0.01 & 0.02 & 0.03 & 0.004 & 0.002 & 0.002 & 0.001 \\
\hline S2 & 0.13 & 0.40 & 0.02 & 0.04 & 0.04 & 0.004 & 0.002 & 0.002 & 0.001 \\
\hline S3 & 0.18 & 0.70 & 0.20 & 0.03 & 0.05 & 0.003 & 0.002 & 0.010 & 0.001 \\
\hline S4 & 0.20 & 0.40 & 0.19 & 0.03 & 0.03 & 0.004 & 0.002 & 0.004 & 0.002 \\
\hline S5 & 0.11 & 1.55 & 0.66 & 0.03 & 0.03 & 0.003 & 0.003 & 0.005 & 0.003 \\
\hline S6 & 0.23 & 1.31 & 0.05 & 0.03 & 0.03 & 0.007 & 0.003 & 0.005 & 0.003 \\
\hline S7 & 0.10 & 0.56 & 0.55 & 0.21 & 0.25 & 0.120 & 0.022 & 0.065 & 0.004 \\
\hline
\end{tabular}


then investigated on an Axio Observer "Carl Zeiss" optical microscope equipped with a computerized image analysis system. Presuming equiaxed shapes of both PAG and ferrite grains, the respective average volumetric diameters $D_{\gamma}$ and $D_{\alpha}$ have been derived from their planar counterparts.

\section{Experimental results}

According to the performed measurements, the dimensions of the PAGs range from 20 to $131 \mu \mathrm{m}$. Among 35 couples of microstructures transformed from both undeformed and deformed austenite, we consider only 24 couples of ferritepearlite structures. Most of them were obtained at cooling rates 1,3 and $10^{\circ} \mathrm{C} / \mathrm{s}$. For steels S1, S2 and S4, structures of this type were also obtained at a rate of $30^{\circ} \mathrm{C} / \mathrm{s}$.

At low cooling rates $\left(1\right.$ and $\left.3^{\circ} \mathrm{C} / \mathrm{s}\right)$, no notable effect of austenite deformation on the temperature of the onset of ferritic transformation is found. At the same time, this effect gains in significance at higher cooling rates that is seemingly due to a weaker recovery of deformed austenite. Similarly, the austenite deformation influences the temperature of the transformation finish, although in this case the effect of the cooling rate effect on the increase in this temperature is less. In all, as expected, the pre-deformation of austenite shifts the transformation range to higher temperatures.

According to the obtained results, the transformation of deformed austenite generally leads to finer ferrite grains. Note that the refinement of ferrite grains due to austenite deformation intensifies with the increasing cooling rate, but remains rather weak. Thus, the average grain sizes at rates 1 , 3 and $10^{\circ} \mathrm{C} / \mathrm{s}$ are $15.5,12.2$ and $10.3 \mu \mathrm{m}$, decreasing by only 2,3 и $10 \%$. Even at a maximum cooling rate of $10^{\circ} \mathrm{C} / \mathrm{s}$, the apparent refinement is comparable to the measurement error. The maximum relative reduction of grain size reaches about $20 \%$ in steels S1, S2 and S6.

\section{Model description}

The above-considered data are employed to calibrate the present model that is an extension of the previous one [14], where the effect of austenite deformation was not considered.

\subsection{Ferrite nucleation}

In any state of austenite (undeformed or deformed), polygonal ferrite is presumed to nucleate at PAGB in two modes. In the first mode, the nucleation sites are the apexes of austenite grains, in the second, their linear junctions (ribs) serve as nuclei of ferrite. On considering 5 apexes per austenite grain and allowing their gradual occupation in time, the volume density $N_{1}^{0}(t)$ of nucleation sites takes on the form [14]:

$$
N_{1}^{0}(t) \cong \frac{10}{D_{\gamma}^{3}}-\Delta N_{1}(t)
$$

where $D_{\gamma}$ is the average grain diameter and $\Delta N_{1}(t)$ is the density of grains nucleated in time $t$, calculated from the moment when the formation of ferrite becomes thermodynamically favorable.

In the second mode, the ferrite nucleation at ribs of the austenite grains is considered. The propagation of ferrite along the ribs and facets is treated so that the current density of the related nucleation sites is expressed by [14]:

$$
N_{2}^{0}(t)=\frac{1}{D_{\gamma}^{2} a_{\gamma}}\left(1-S_{\alpha}(t)\right),
$$

where $a_{\gamma}$ is the austenite lattice parameter and $S_{\alpha}(t)$ is the PAGB fraction occupied by ferrite at time $t$.

Since the ferrite nucleation is a thermo-activated lattice rearrangement, the austenite deformation effect on the considered modes $(k=1,2)$ at current time $t$ at absolute temperature $T$ is revealed in terms of the classical nucleation theory [14] modified as proposed in [9]. The resulting nucleation rate is:

$$
\begin{aligned}
& J_{k}\left(T, Y_{A E}, \varepsilon, t, t_{C}\right)= \\
& =C_{k} N_{k}^{0}(t) \exp \left(-\frac{Q_{N}\left(Y_{A E}\right)}{R_{g} T}\right) \exp \left(-\frac{\psi_{k}^{P F}\left(\varepsilon, t_{C}\right) \sigma_{k}^{3}}{k_{B} T \Delta G_{\gamma \rightarrow \alpha}^{2}\left(T, Y_{A E}, \varepsilon, t_{C}\right)}\right) .
\end{aligned}
$$

In this expression, $Q_{N}\left(Y_{A E}\right)$ is the activation energy of the lattice rearrangement, $Y_{A E}=\left\{y_{\mathrm{C}}, y_{\mathrm{Mn}}, y_{\mathrm{Si}}, \ldots\right\}$ represents a set of average fractions of the sites of substitution and interstitial sublattices occupied, respectively, by the atoms of substitution alloying elements and carbon. Parameter $\sigma_{k}$ expresses the effective specific energy of the $\gamma / \alpha$-interface, $\Delta G_{\gamma \rightarrow \alpha}\left(T, Y_{A E}, \varepsilon, t_{C}\right)$ is the transformation driving force dependent on the strain degree $\varepsilon$ of austenite, time $t_{C}$ is counted from the end of deformation, factor $\Psi_{k}^{P F}\left(\varepsilon, t_{C}\right)$ is equal to unity in case of no pre-deformation and allows for variation of nucleation barriers in deformed austenite due to alternate signs of internal hydrostatic stresses at the boundaries [11]. Boltzmann's constant and universal gas constant are conventionally denoted by $k_{B}$ and $R_{g}$.

The transformation driving force $\Delta G_{\gamma \rightarrow \alpha}\left(T, Y_{A E}, \varepsilon, t_{C}\right)=$ $=\Delta G_{\gamma \rightarrow a}^{0}\left(T, Y_{A E}\right)+\Delta G_{\gamma \rightarrow a}^{d}\left(\varepsilon, t_{C}\right)$ involves both the term $\Delta G_{\gamma \rightarrow a}^{0}\left(T, Y_{A E}\right)$ peculiar to undeformed austenite and the specific contribution of deformation $\Delta G_{\gamma \rightarrow a}^{d}\left(\varepsilon, t_{C}\right) \cong$ $\cong-0.5 b^{2} \mu \bar{\rho}_{d}\left(\varepsilon, t_{C}\right)$, where $b$ is the Burgers vector magnitude, $\mu$ is the shear modulus and $\bar{\rho}_{d}\left(\varepsilon, t_{C}\right)$ is the average dislocation density. Based on the general expression for the dislocation part of the work hardening and allowing for recovery (see Eq. (6)), we employ:

$$
\bar{\rho}_{d}\left(\varepsilon, t_{C}\right)=\left(\frac{\Delta \sigma\left(\varepsilon, t_{C}\right)}{\alpha_{\rho} M \mu b}\right)^{2},
$$

where $M=3.1$ is the Taylor factor and $\alpha_{\rho} \cong 0.15$. The temperature dependence of $\mu=\mu(T)$ is evaluated according to [15]. Factor $\Psi_{k}^{P F}$ is expressed according to [9]: $\Psi_{k}^{P F}=\left(1+3 \xi_{k}+\xi_{k}^{2}\right)\left(1+\xi_{k}\right)^{-3}$, where $\xi_{k}$ is proportional to the driving force variation due to hydrostatic stresses induced in the interaction of deformed austenite grains. With allowance for the relative volume change $\delta_{y \rightarrow a}$ in the transformation, we consider the driving force dispersion proportional to $\left(\delta_{\gamma \rightarrow a} \Delta \sigma\left(\varepsilon, t_{C}\right)\right)^{2}$ and thus obtain [9]:

$$
\xi_{k} \equiv \xi_{k}\left(t_{C}\right)=\alpha_{\xi_{k}} \frac{\alpha_{\gamma}^{4}\left(\delta_{\gamma \rightarrow \alpha} \Delta \sigma\left(\varepsilon, t_{C}\right)\right)^{2}}{\sigma_{k} k_{B} T},
$$

where $\alpha_{\xi k}$ are empirical coefficients $(k=1,2)$. At $\xi_{k}>0$ parameter $\Psi_{k}^{P F}<1$ and monotonously diminishes with growing $\xi_{k}$. Hence, the higher the dispersion of the driving force proportional to $\left(\delta_{\gamma \rightarrow a} \Delta \sigma\left(\varepsilon, t_{C}\right)\right)^{2}$, the lower the effective 
barrier value in Eq. (3) providing an exponential increase in the nucleation rate.

The weakening of work hardening due to recovery is expressed according to [16]:

$$
\begin{aligned}
& \frac{d \Delta \sigma\left(\varepsilon, t_{C}\right)}{d t}= \\
& =-\frac{64 \Delta \sigma\left(\varepsilon, t_{C}\right)^{2} v_{d}}{9 M^{3} \alpha_{\rho}^{2} E(T)} \exp \left(-\frac{U_{r e c}}{R_{g} T}\right) \sinh \left(\frac{\Delta \sigma\left(\varepsilon, t_{C}\right) V_{r e c}}{k_{B} T}\right) .
\end{aligned}
$$

where $U_{\text {rec }}$ and $V_{r e c}$, respectively, are the activation energy and the volume of the recovery process that are assumed to be equal to $286 \mathrm{~kJ} / \mathrm{mol}$ and $45 b^{3}$ [15]; $v_{D}$ is the Debye frequency set to be $2 \times 10^{12} \mathrm{~s}^{-1}, E(T)=2.6 \mu(T)$ is the Young's modulus. To integrate Eq. (6), the initial condition $\Delta \sigma\left(\varepsilon, t_{C}=0\right)=\sigma_{\varepsilon}-\sigma_{y}$, is used, where $\sigma_{\varepsilon}$ is the deforming stress of austenite, dependent on the strain degree, strain rate and temperature according to [17], and $\sigma_{y} \equiv \sigma_{0.2}$ is the yield stress of austenite similarly calculated at its plastic strain of $0.2 \%$.

We consider the activation energy $Q_{N}$ of the diffusional lattice rearrangement equal to the activation energy of the grain boundary self-diffusion estimated as a half of activation energy $Q_{S D}$ of the bulk self-diffusion. To simplify modeling, the known dependence of $Q_{S D}$ on the chemical composition $Y_{A E}$ according to [18],

$$
\begin{aligned}
Q_{S D}\left(Y_{A E}\right)= & 311691-278242\left(1-\exp \left(-0.394 y_{\mathrm{C}}\right)\right)+ \\
& +88752 y_{\mathrm{Mn}}^{0.31}+22801 y_{\mathrm{Si}}-6490 y_{\mathrm{Cr}}+ \\
& +84864 y_{\mathrm{Mo}}^{0.65}-38575 y_{\mathrm{Ni}}^{0.3}-7298 y_{\mathrm{V}}+ \\
& +132594 y_{\mathrm{Nb}}{ }^{0.263}+82128 y_{\mathrm{Ti}}^{0.401}(\mathrm{~J} / \mathrm{mol})
\end{aligned}
$$

can be utilized by $Q_{N}\left(Y_{A E}\right)=0.5 Q_{S D}\left(Y_{A E}\right)$.

\subsection{Additional components of the model}

The ferrite growth rate is treated in terms of "mixed kinetics" [14,19] where the movement of the $\gamma / \alpha$-interface is controlled by both its mobility and the rate of carbon displacement from the interface to the volume of austenite grain. The growth rate in the general case is determined by the most hindering factor of the two.

Following [14], volume increments $\mathrm{d} v_{1}$ and $\mathrm{d} v_{2}$ of ferrite nucleated in the first and second modes, respectively, are calculated with allowance for the grain "hard collisions". The ferrite nucleation is completed at time $t_{N}$, where this phase covers the entire area of the austenite boundaries: $S_{\alpha}\left(t_{N}\right)=1$. Next, rapid increments $d S_{\alpha}$ along the austenite boundaries are also determined according to [14]. Besides, this paper describes the calculation of the employed thermodynamic parameters (driving force $\Delta G_{\gamma \rightarrow a}^{0}\left(T, Y_{A E}\right)$ of transformation of undeformed austenite and equilibrium carbon concentrations $\left(y_{\mathrm{C}_{\gamma}}, y_{\mathrm{C}_{\alpha}}\right)$ in both phases) dependent on the temperature and chemical composition.

The average volumetric diameter of ferrite grains that is an important characteristic of ferrite-pearlite structures is expressed according to [21]: $D_{\alpha}=1.5 \times\left(2 X_{\alpha} / 3 N_{\alpha}\right)^{1 / 3}$, where $X_{\alpha}$ is the volume fraction of ferrite, $N_{\alpha}=N_{1}\left(t_{N}\right)+N_{2}\left(t_{N}\right)$ is the number of grains per unit volume. The model used for pearlitic transformation is also described in [14].

\section{Model calibration, modeling results and their discussion}

The empirical parameters of the model, except for $\alpha_{\xi 1}$ and $\alpha_{\xi 2}$, are determined in [14]. The mentioned two values are found with allowance for the accumulated database on the transformation kinetics of deformed austenite, as well as on the size of ferrite grains in the corresponding structures. The set of considered parameters is optimized to minimize the difference between the model and experimental curves for the transformation kinetics as well as between the predicted and measured sizes of ferrite grains. The problem is solved with allowance for 24 kinetic curves and corresponding data on the grain sizes. The calculations have been implemented with authors' model/software AusEvol Pro [22] that enables quantification of the microstructure evolution both during hot deformation of austenite and during its transformation in cooling, where the main structural constituents (ferrite, perlite, bainite and martensite) are specifically allowed for. The previous version of this model [14] has been modified to simulate the ferritic transformation with allowance for the austenite deformation effect.

Input $a_{\gamma}=0.364 \mathrm{~nm}, \quad \delta_{\gamma \rightarrow \alpha}=0.02, \quad \sigma_{1}=0.016 \quad$ and $\sigma_{2}=0.028 \mathrm{~J} / \mathrm{m}^{2}$ [14] (see Eq. (5)) resulted in $\alpha_{\xi_{1}}=1.82 \times 10^{3}$, $\alpha_{\xi_{2}}=2.92 \times 10^{3}$. Other conditions being equal, these results mean that the rate of nucleation of ferrite grains in the second mode (at ribs of grains) increases stronger with respect to the first mode (at grain apexes). This complies with the appearance of hydrostatic stresses just at the grain ribs [11], whereas the stresses around grain apexes require further analysis.

Fig. 1 enables comparing the calculated kinetics of ferriticpearlitic transformation with the respective experimental data for several investigated steels. Evidently, the modeling results comply satisfactorily with the experiments. Verification of the predicted ferrite grain sizes obtained from both undeformed and deformed austenite is satisfactory as well. The relative errors of these predictions, averaged over all considered steels, are, respectively, 10.8 and $13.2 \%$.

\section{Conclusions}

Based on the obtained experimental data, a physically motivated model is formulated for the ferrite transformation with allowance for the effects of deformation and concurrent recovery of austenite both on the nucleation and on the growth of ferrite grains. To predict properly the nucleation rate, the variation of nucleation barriers at the austenite grain boundaries is considered, which is due to the hydrostatic component of deformation-induced internal stresses. The present model is first to allow for this effect exponentially increasing the nucleation rate. The simulated kinetics of the ferritic-pearlitic transformation in the investigated steels satisfactorily comply with the experiments. Experimental verification of the ferrite grain sizes predicted for both undeformed and deformed austenite is satisfactory as well. The relative errors of these predictions, averaged over all considered steels, are 10.8 and $13.2 \%$, respectively.

Acknowledgements. The authors are grateful to Prof. Alexander Zisman for useful discussions of the paper. This work was supported by the grant from the Russian Science Foundation (project No. 19-19-00281). 


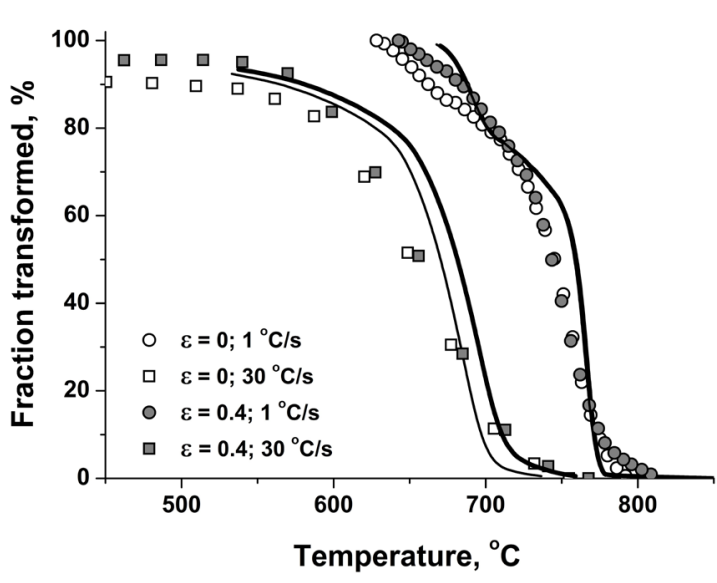

a

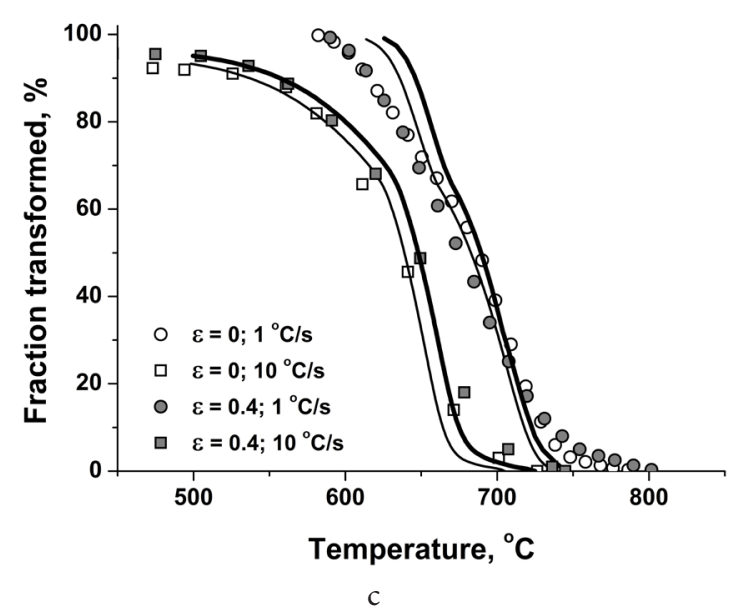

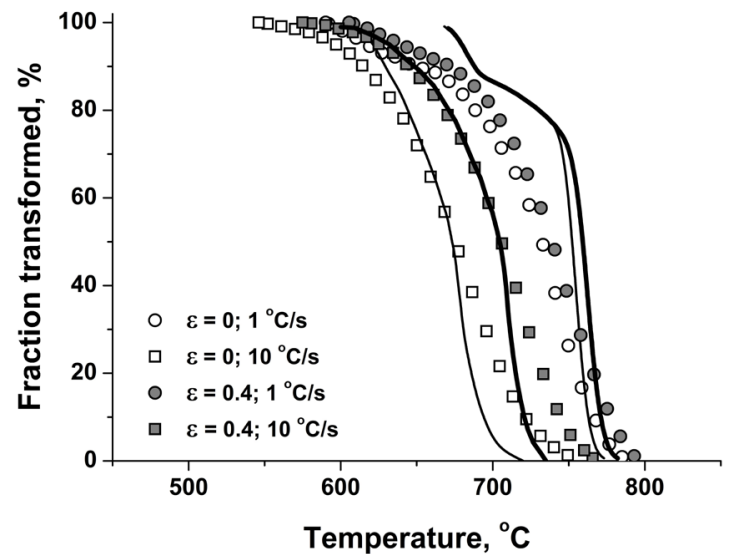

b

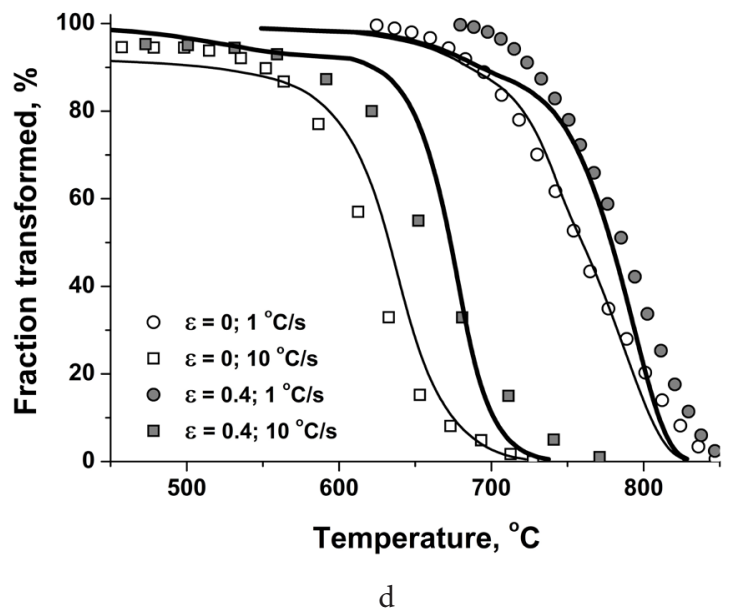

Fig. 1. Austenite transformation kinetics by the model (lines) and experiments (symbols) for steels S3 (a), S5 (b), S6 (c) and S7 (d).

\section{References}

1. M. Militzer. In: Comprehensive Materials Processing. V. 1. Assessing Properties of Conventional and Specialized Materials (ed. by S. Hashmi, C. J. Van Tyne). Elsevier (2014) p. 191

2. A.M. Ravi, A. Kumar, M. Herbig, J. Sietsma, M. J. Santofimia. Acta Mater. 188, 424 (2020). Crossref

3. E. Essadiqi, J. J. Jonas. Metall. Trans. A. 19, 417 (1988). Crossref

4. M. Umemoto, A. Hiramatsu, A. Moriya, T. Watanabe, S. Nanba, N. Nakajima, G. Anan, Y. Higo. ISIJ Int. 32 (3), 306 (1992). Crossref

5. R. Pandi, M. Militzer, E. B. Hawbolt, T. R. Meadowcroft. 37th Mechanical Working and Steel Processing Conference Proceedings. XXXIII, 635 (1996).

6. D. N. Hanlon, J. Sietsma, S. Zwaag. ISIJ Int. 41 (9), 1028 (2001). Crossref

7. Y. J. Lan, N. M. Xiao, D. Z. Li, Y. Y. Li. Acta Mater. 53, 991 (2005). Crossref

8. A. Yamanaka, T. Takaki, Y. Tomita. ISIJ Int. 52 (4), 659 (2012). Crossref

9. V. G. Karpov. Phys. Rev. B. 50 (13), 9124 (1994). Crossref

10. V.G. Karpov, D. W. Oxtoby. Phys. Rev. B. 54 (14), 9734 (1996). Crossref

11. A. A. Zisman, V.V. Rybin. Acta Mater. 46 (2), 457 (1998). Crossref
12. C. Ghosh, C. Aranas, J. J. Jonas. Prog. Mater. Sci. 82, 151 (2016). rossref

13. Thermo-Calc Software

14. A. Vasilyev, D. Sokolov, N. Kolbasnikov, S. Sokolov. Phys. Solid State. 54 (8), 1669 (2012). Crossref

15. H. S. Zurob, C. R. Hutchison, Y. Brechet, G. Purdy. Acta Mater. 50, 3075 (2002). Crossref

16. M. Verdier, Y. Brechet, P. Guyot. Acta Mater. 47 (1), 127 (1999). Crossref

17. A. Vasilyev, A. Rudskoy, N. Kolbasnikov, S. Sokolov, D. Sokolov. Mater. Sci. Forum. 706-709, 2836 (2012). Crossref

18. A. A. Vasilyev, S. F. Sokolov, N.G. Kolbasnikov, D. F. Sokolov. Phys. Solid State. 53 (11), 2194 (2011). Crossref

19. B. Y. Liubov. Kinetic theory of phase transformations. Moscow, Metallurgiya (1969) 206 p. (in Russian) [Б. Я. Любов. Кинетическая теория фазовых превращений. Москва, Металлургия (1969) 206 с.]

20. A.A. Vasilyev, P.A. Golikov. Models for calculating carbon diffusion coefficient in steels and examples of their practical use. St. Petersburg, SPbPU (2019) 184 p. (in Russian) [А.А. Васильев, П.А. Голиков. Модели для расчета коэффициента диффузии углерода в сталях и примеры их практического использования. Санкт-Петербург, СПбПУ (2019) 184 с.]

21. Y. Saito, C. Shiga. ISIJ Int. 32 (3), 414 (1992). Crossref

22. A. Vasilyev, D. Sokolov, S. Sokolov, N. Kolbasnikov. Mater. Sci. Forum. 2020 (to be published). 